logos_i_ethos_2020_2_(55), s. 189-206

DOI: http://dx.doi.org/10.15633/lie.3813

Krzysztof Szymoniak

https://orcid.org/0000-0002-9346-8635

Akademia Ignatianum w Krakowie

\title{
W poszukiwaniu aksjologicznych podstaw dla etyki działań biotechnologicznych
}

Biotechnologia stanowi jedną z najszybciej rozwijających się dziedzin nauki. W jej ramach dochodzi do poznania skomplikowanych procesów biologicznych zachodzących w organizmach żywych. To umożliwia coraz efektywniejsze wykorzystanie zdobytej wiedzy w najróżniejszych obszarach życia człowieka ${ }^{1}$.

Krzysztof Szymoniak - doktorant na Wydziale Filozoficznym Akademii Ignatianum w Krakowie. Prowadzi badania w zakresie etyki badań biomedycznych. Bioetyk, absolwent podyplomowych studiów z bioetyki na UPJPII oraz studiów magisterskich z biotechnologii na Uniwersytecie Przyrodniczym w Poznaniu. Pracuje jako niezależny specjalista do spraw badań klinicznych.

Pomimo niewątpliwych korzyści biotechnologia rodzi też wiele problemów natury etycznej. Naukowcy zyskali narzędzia, jakimi wcześniej nie dysponowali. Przykładowo, przy pomocy metod genetyki i biologii molekularnej zdolni są do aktywnego ingerowania w procesy zachodzące w organizmach żywych, w tym tworzenia lub modyfikowania ludzkiego organizmu na bardzo wczesnym etapie jego rozwoju. $Z$ tego powodu od wielu lat pojawiają się głosy nawołujące do poważnego namysłu etycznego nad kierunkiem rozwoju biotechnologii.

Nierzadko biotechnologia jako nauka uznawana jest za etycznie neutralną, co oznacza, iż jedynie jej konkretne zastosowania powinny podlegać kwalifikacji moralnej. Takie podejście oznaczałoby, iż wszystko

1 Por. A. Chmiel, Biotechnologia. Podstawy mikrobiologiczne i biochemiczne, Warszawa 1998, s. 18. 
co technicznie możliwe, byłoby dopuszczalne, dopóki pozostaje na etapie wstępnych badań prowadzonych przez biotechnologów w laboratoriach i nie jest wdrażane do szerszego zastosowania. Czy rzeczywiście jedynie zastosowania biotechnologii wdrażane na szerszą skalę rodzą wątpliwości natury etycznej, a sam proces prowadzenia badań naukowych w ramach biotechnologii jest wolny od kwestii o charakterze moralnym?

W moim artykule podejmę próbę odnalezienia odpowiedzi na wyżej postawione pytanie, zwracając szczególną uwagę na aksjologiczny i etyczny wymiar biotechnologii. Zacznę od próby określenia, czym jest nauka oraz jakiego rodzaju nauką jest biotechnologia, aby następnie zastanowić się, czy biotechnolog w swojej pracy badawczej natrafia na wartości zakorzenione $\mathrm{w}$ wewnętrznej strukturze nauki. W dalszej części artykułu podejmę próbę odpowiedzi na pytanie: „Czy z faktu obecności lub braku wartości w tych naukach płyną jakieś konsekwencje lub powinności dla badaczy, szczególnie w kontekście ich odpowiedzialności moralnej?". Na końcu przejdę do tematu poszukiwań ogólnych podstaw dla etyki działań biotechnologicznych z uwzględnieniem przesłanek antropologicznych. Ze względu na fakt, że największe dylematy etyczne dotyczą badań biomedycznych, których przedmiotem jest człowiek, przedstawione niżej analizy ograniczę głównie do biotechnologii człowieka.

\section{Biotechnologia jako nauka}

Na wstępie niezbędne wydaje się doprecyzowanie, czym w zasadzie jest nauka oraz jakiego rodzaju nauką jest biotechnologia. Zgodnie z ogólną definicją nauka to uzyskanie uporządkowanej wiedzy w pewnej dziedzinie na temat ściśle określonego przedmiotu, rozważanego w jakimś aspekcie, przy pomocy specjalnie dobranych metod. W zależności od celu może ona mieć charakter praktyczny lub teoretyczny. Naukę można rozumieć w trzech głównych aspektach: 1) nauka jako wytwór ludzkiego poznania (wiedza); 2) nauka jako zespół czynności poznawczych prowadzących w sposób metodyczny do zdobywania wiedzy; 
3) zastosowania wyników badań naukowych, a więc zdobytej wiedzy w różnych sferach ludzkiej działalności ${ }^{2}$.

Dodatkowo warto dokonać odróżnienia nauki rozumianej w sensie czynnościowym (wszelkie aktywności wchodzące w skład badania naukowego) od nauki w sensie wytworowym (wiedza zdobyta podczas czynności badawczych). Z punktu widzenia dalszych analiz etycznych ważniejszy jest oczywiście aspekt czynnościowy biotechnologii, gdyż to on bezpośrednio wiąże się działaniem człowieka, które to jednocześnie stanowi przedmiot kwalifikacji moralnej.

W starożytności wiedza zdobywana była w celu lepszego zrozumienia świata. Dla Arystotelesa ideałem nauki była teoria, czyli bezinteresowna kontemplacja rzeczywistości. Intencją człowieka było zatem poznanie natury rzeczy, a więc prawdy rozumianej jako zgodność sądów $\mathrm{z}$ rzeczywistością. Nauka w klasycznym rozumieniu przyczynia się do wielowymiarowego poznania świata. Dzięki działalności naukowej człowiek odkrywa prawa rządzące światem oraz gromadzi wiedzę $\mathrm{w}$ formie zbioru twierdzeń.

Współczesny model nauki wybiega wyraźnie poza teoretyczną refleksję nad światem. Od czasów Francisa Bacona nauka ma służyć przede wszystkim celom praktycznym, istnieje też przekonanie, że naturę świata, oprócz jej poznawania, można także zmieniać. Postęp naukowy związany jest zatem nie tylko z poszerzaniem wiedzy teoretycznej o świecie, lecz także z kierunkiem wykorzystania tej wiedzy. Jak zauważa Erwin Chargaff, era nauki ,jako niekończącego się poszukiwania prawdy o naturze, poszukiwania, które miało pomóc nam zrozumieć funkcjonowanie świata, skończyła się. Zaczęła się nowa era; nauka jest teraz rzemiosłem, sztuką manipulowania, modyfikowania i ukierunkowywania sił natury"4.

2 Por. A. Stępień, Wstęp do filozofii, Lublin 2007, s. 16-18.

3 Por. A. Lekka-Kowalik, Związek nauki i techniki jako źródło problematyki dla etyki badań naukowych, w: Kultura wobec techniki, red. P. Gondek i in., Lublin 2004, s. 147-165.

4 Za: A. Paszewski, Sukcesy naukowe a problemy etyczne, „Postępy Mikrobiologii” 39 (2000), s. 9-15. 
Na obecnym poziomie rozwoju nauki, a szczególnie w dziedzinach biomedycznych, działalność badawcza nie ogranicza się jedynie do teoretycznego, dedukcyjnego „odczytania” reguł panujących w świecie, lecz sam proces poznania zakłada pewną ingerencję $\mathrm{w}$ przedmiot badania. Odbywa się ona najczęściej przy użyciu skomplikowanych metod doświadczalnych. Biotechnologia stanowi tutaj doskonały przykład.

Od początku powstania biotechnologii jako nauki pojawiło się wiele różnych jej definicji. Jedna $\mathrm{z}$ nich, wymieniona w konwencji o różnorodności biologicznej ONZ z 1992 roku, określa biotechnologię jako wykorzystanie technologiczne systemów biologicznych, organizmów żywych lub ich składników w celu wytwarzania lub modyfikowania produktów w celu określonego ich zastosowania ${ }^{5}$. W definiowaniu biotechnologii najczęściej akcentuje się wymiar aplikacyjny wiedzy zdobytej w ramach różnych nauk biologicznych ${ }^{6}$. Takie spojrzenie na biotechnologię wydaje się nieco uproszczone i jest wyrazem utrwalonego przez lata klasycznego podziału nauk przyrodniczych na podstawowe i stosowane. Uznając ten podział, takie nauki jak np. biologia, biochemia, mikrobiologia byłyby zaliczone do nauk podstawowych, a biotechnologia do nauk stosowanych. Uogólniając, podział ten trwa do dziś. Współcześnie granica uległa jednak wyraźnemu zatarciu, w efekcie czego, w ramach współczesnej biotechnologii, te dwa rodzaje badań wzajemnie się przenikają i uzupełniają.

W laboratoriach biotechnologicznych podczas opracowywania różnorodnych metod planowanego i celowego wykorzystania organizmów żywych w różnych obszarach nierzadko dochodzi do poszerzenia wiedzy na temat zachodzących procesów biologicznych. Obserwujemy także zjawisko odwrotne. Biolodzy pracujący nad poznawaniem procesów biologicznych w organizmach żywych często stosują metody, które zawdzięczają biotechnologii. Trudno zatem uznać biotechnologię za dziedzinę, w której dochodzi jedynie do wykorzystania moralnie neutralnych

5 Por. P. Kafarski, Tęczowy kod biotechnologii, „Chemik” 66 (2012) nr 8, s. 811-816.

${ }^{6}$ Por. S. Dorocki, J. P. Jastrzębski, Regionalne zróżnicowanie rozwoju biotechnologii w Europie, „Prace Komisji Geografii Przemysłu Polskiego Towarzystwa Geograficznego” 20 (2012), s. 67-94. 
osiągnięć zdobytych w innych dyscyplinach biomedycznych. Dostarcza bowiem nie tylko odpowiednich technik, ale i konkretnej wiedzy umożliwiającej wykorzystanie potencjału biologicznego organizmów żywych.

Współczesną biotechnologię można byłoby więc uznać za naukę, która obejmuje wszystkie wymienione wyżej aspekty. Dla biotechnologa w zakres pojęcia „nauka” wchodziłyby nie tylko praktyczne zastosowania zdobytej wcześniej wiedzy w ściśle określanym celu, ale także wszelkie czynności badawcze prowadzące do jej zdobycia czy poszerzenia ${ }^{7}$. W obszarze biotechnologii związek nauki i techniki jest ścisły i nierozerwalny. W tak rozumianym kontekście biotechnologię należałoby uznać zatem zarówno za naukę stosowaną, jak i naukę, w której znajdujemy obszary badawcze tradycyjnie uznawane za należące do nauk podstawowych.

Takie ujęcie biotechnologii skutkuje uznaniem jej za naukę, w której prowadzone są badania naukowe składające się na większy proces wiedzotwórczy, a nie jedynie za technologię, którą wykorzystuje się w różnych obszarach życia człowieka. To doprecyzowanie wydaje się mieć istotne znaczenie w próbie nakreślenia aksjologicznego i etycznego wymiaru biotechnologii oraz odpowiedzi na postawione we wstępie pytanie: „Czy biotechnologia jest etycznie neutralna, a jedynie jej zastosowania podlegają kwalifikacji etycznej?”.

\section{Biotechnolog wobec wartości}

Bez wątpienia przedmiotem materialnym biotechnologii jako nauki nie są wartości - nie są przecież uchwytne empirycznie, a więc nie mogą być badanie przy pomocy metodologii stosowanej w naukach przyrodniczych. Jednak trudno nie zgodzić się z faktem, iż biotechnolog, zarówno

7 Według Organizacji Współpracy Gospodarczej i Rozwoju (OECD) biotechnologia to dziedzina nauki i techniki zajmująca się zmianą materii żywej i nieożywionej poprzez wykorzystanie organizmów żywych, ich części bądź pochodzących od nich produktów, w celu tworzenia wiedzy, dóbr i usług. Podana definicja uwzględnia zastosowanie organizmów żywych nie tylko w produkcji, ale także w poszerzaniu wiedzy; por. A. Dubin, Stan i kierunki rozwoju biogospodarki, w: Raport opracowany przez Interdyscyplinarny Zespót do spraw Rozwoju Biogospodarki MNiSW, Warszawa 2007. 
jako człowiek, jak i pracownik naukowy, doświadcza obecności wartości podczas swojej pracy - bez nich trudno byłoby odnaleźć sens wykonywanego przez niego zawodu. $Z$ jakimi zatem podstawowymi wartościami może mieć do czynienia biotechnolog?

W centrum zainteresowania biotechnologa są oczywiście organizmy żywe. Za pierwszą i podstawową wartość, jaką napotyka biotechnolog, możemy zatem uznać wartość życia. Zarówno życie jako fenomen, jak i wszelkie jego przejawy stanowią część zastanego przez człowieka porządku natury. Przyroda wraz ze składającymi się na nią wszystkimi organizmami żywymi to dla biotechnologa swoisty świat wartości. Oprócz samego przedmiotu swoich badań biotechnolog styka się również z wartościami, które obecne są w procesie uprawiania nauki. W pierwszej kolejności szczególnie wyraźnie ujawnia się nam wartość wiedzy, jaką dostarcza praktyka naukowa. Poszerzenie zrozumienia rzeczywistości świata, w którym żyjemy, daje nam z kolei olbrzymią wartość wykorzystania tej wiedzy w najróżniejszych kierunkach działalności człowieka.

Biorąc pod uwagę wartości związane z pracą badawczą, biotechnolog, jako naukowiec, pełni doniosłą rolę społeczną. W tym kontekście nie tylko staje on w obliczu wartości, ale - ze względu na istotne znaczenie wykonywanego zawodu - w dużej mierze również je tworzy. Stąd ważnym aspektem staje się zagadnienie zawodowej odpowiedzialności za wartości obecne w pracy naukowej. Poszanowanie wartości w konsekwencji będzie się wiązać z działaniem na rzecz dobra. Biotechnolog zatem powinien dostrzegać problemy związane ze szczególną specyfiką uprawianej przez niego dziedziny nauki. Od przyjętej etyki, a więc systemu norm etycznych, zależą moralne decyzje biotechnologa, wpływające na sposób prowadzenia badań naukowych.

Jest to ważne szczególnie dziś, w czasach, w których biotechnolodzy mogą trwale ingerować w biologię organizmów żywych. Przykładowo, metody używane $w$ inżynierii genetycznej umożliwiają ingerencje nie tylko w biologię pojedynczej komórki lub organizmu, lecz także w trwałe zmiany w genomie organizmów (w tym człowieka). Zmiany te mogą już nie tylko wpływać na funkcjonowanie pojedynczego organizmu, lecz dotyczyć biologii całych gatunków i ekosystemów, w których te pierwsze 
żyją. Pojawiają się wyzwania, z jakimi biotechnolog musi zmierzyć się sam. Do takich sytuacji można zaliczyć chociażby problem przeprowadzania zapłodnienia in-vitro, selekcji zarodków, wykorzystania ludzkich zarodkowych komórek macierzystych czy trwałych modyfikacji genetycznych ludzkich embrionów. W pewnych okolicznościach biotechnolog może więc stanąć nie wobec wartości, ale wobec antywartości. Nie wszystko bowiem, co technicznie możliwe, powinno być realizowane $\mathrm{w}$ nauce, nawet jeśli może się wiązać z poszerzeniem wiedzy lub osiągnięciem założonego celu.

\section{Aksjologiczny wymiar biotechnologii}

Spór o obecność wartości poznawczych w nauce

Powyżej przedstawiono propozycję przykładowego doświadczenia wartości przez biotechnologa. Warto jednak zastanowić się, czy intuicje te mają uzasadnienie $\mathrm{w}$ rozwijanych $\mathrm{w}$ ramach aksjologii nauki koncepcjach filozoficznych.

Na gruncie aksjologii nauki podejmuje się m.in. analizę czynności badawczych i wiedzotwórczych pod kątem obecności w nich wszelkich wartości oraz sądów wartościujących. Celem aksjologicznej refleksji nad naturą nauki jest określenie, czy nauka jest w swej wewnętrznej strukturze nierozerwalnie związana z wartościami („nasycona wartościami”) czy też od tych wartości wolna. Jeśli uznać, że pewne wartości są w niej obecne, kluczowa w tej analizie będzie odpowiedź na pytanie, jaki jest wpływ dokonywanych przez badaczy wartościowań, ocen i wyborów na elementy składowe całego procesu poznawczego.

Warto na samym wstępie zaznaczyć, że nie chodzi tu wcale o ocenę nauki, działań naukowych, metod przez nią stosowanych czy wreszcie jej rozmaitych zastosowań niejako z zewnątrz, z różnych perspektyw. Taka ocena jest oczywiście dokonywana nie tylko przez samych naukowców, ale i ekonomistów, prawników, polityków lub etyków. Nie chodzi także o wartość zdobytej wiedzy, gdyż ta najczęściej traktowana jest jako wartość sama w sobie. W tych rozważaniach fundamentalne będzie 
zastanowienie się, czy naukowiec jest uprawniony do wydawania sądów wartościujących, a jeśli tak, to jaką rolę sądy te pełnią w wewnętrznej strukturze nauki i czy nie zagrażają one jej obiektywności ${ }^{8}$.

W okresie pozytywistycznego rozwoju myśli naukowo-technicznej wartości oraz sądy wartościujące zostały usunięte $\mathrm{z}$ wewnętrznej struktury nauki ${ }^{9}$. Kluczowym argumentem było uznanie, iż obecność wartości (w tym sądów wartościujących) stanowi zagrożenie dla obiektywnego charakteru nauki. W ten sposób narodziła się koncepcja „nauki wolnej od wartości” czy też „nauki neutralnej wobec wartości”" ${ }^{10}$. Max Weber, jeden z propagatorów neutralności aksjologicznej nauki, postulował, aby badacz w analizach odróżniał ustalenia faktów empirycznych od własnej postawy wartościującej ${ }^{11}$. W postulacie tym chodziło zatem o to, aby w badaniach naukowych postawić wyraźną granicę między sądami faktualnymi, należącymi do obiektywnej wiedzy, a sądami wartościującymi, będącymi wyrazem własnych przekonań badacza. Rozróżnienie tych dwóch typów sądów, zdaniem Webera, było podstawowym warunkiem zachowania rzetelności naukowej. W praktyce oznaczałoby to, że wszelkie twierdzenia naukowe (hipotezy, teorie, prawa) powinny być całkowicie wolne od sądów wartościujących na temat badanych przedmiotów lub zjawisk ${ }^{12}$.

Przedstawiona interpretacja wydaje się sprzeczna $\mathrm{z}$ przedstawionym wyżej doświadczeniem biotechnologa. Odnosząc się do historii rozwoju filozofii nauki, należy zauważyć, że wzrastało przekonanie, iż nie tylko nauka sama w sobie jawi się jako wartość, ale jest wartościami „nasycona”. Pojawiała się stopniowo świadomość roli, jaką wartości oraz sądy wartościujące pełnią w wewnętrznej strukturze nauki. Okazało się, że pewne wartościowania, oceny czy wybory są obecne nie tylko w ramach

8 Por. A. Lekka-Kowalik, Odkrywanie aksjologicznego wymiaru nauki, Lublin 2008, s. 364-365.

9 Por. J. Rodzeń, W stronę aksjologii nauki, „Zagadnienia Filozoficzne w Nauce” 24 (1999), s. 3-6.

10 Por. A. Lekka-Kowalik, Odkrywanie aksjologicznego wymiaru nauki, Lublin 2008, s. 5.

11 Zob. M. Weber, Sens wolnej od wartościowań socjologii i ekonomii, w: Problemy socjologii wie$d z y$, red. E. Nowakowska-Sołtan, Warszawa 1985, s. 111.

12 Por. A. Lekka-Kowalik, Odkrywanie aksjologicznego wymiaru nauki, dz. cyt., s. 90. 
kontekstu odkrycia, lecz wchodzą w zbiór wewnętrznych cech nauki, rozumianej jako pewien wielowymiarowy, społeczny proces poznawczy ${ }^{13}$. Każde badanie naukowe jest przecież ciągiem wielu złożonych decyzji, dotyczących m.in. takich kwestii, jak: wybór problemu badawczego, sformułowanie odpowiedniej hipotezy, dobór adekwatnych środków oraz metod czy też wybór najlepszej teorii wyjaśniającej zgromadzone wyniki. Na każdym etapie działalności naukowej badacz dokonuje zatem wielu ocen i sądów wartościujących, które stanowią integralny element procesu poznawczego ${ }^{14}$. Dostrzeżenie wartości w nauce doprowadziło zatem do uznania, że działalność badawcza wymaga nieustannego wartościowania wielu elementów składowych procesu badawczego, a sądy wartościujące są nierozłączną częścią nauki. Zaznaczono jednak, iż w sądach tych mogą być obecne jedynie tzw. wartości poznawcze, czyli takie, które pełnią wyłącznie funkcję poznawczą ${ }^{15}$.

Spór o obecność wartości moralnych w nauce

W środowisku filozofów nauki zaakceptowanie obecności wartości poznawczych i sądów wartościujących poznawczo nastąpiło bez podobnych sporów, jakie najczęściej obserwujemy w ramach dyskusji nad problemami filozoficznymi. Nierozstrzygniętym problemem pozostało jednak, czy wartości inne niż poznawcze (np. wartości moralne), również są nierozerwalnym elementem nauki. Dokładne zrelacjonowanie kształtu dyskusji nad tą kwestią wymagałoby odrębnego opracowania.

13 Jest to przyznanie wsobnego wymiaru aksjologicznego nauki; o zmianie, jaka nastąpiła w filozofii nauki w tej kwestii, McMullin pisze w następujący sposób: „wiek wcześniej niemal wszyscy, którzy pisali o naturze nauki, zgodziliby się, że nauka powinna być «wolna od wartości» [value-free]. Wiek później maksyma, że wiedza naukowa jest «nasycona wartościami» [value-laden], wydaje się równie mocno ugruntowana, jak wcześniej [maksyma] jej przeciwna" - cytat za A. Lekka-Kowalik, Odkrywanie aksjologicznego wymiaru nauki, dz. cyt., s. 5.

14 Por. A. Lekka-Kowalik, Odkrywanie aksjologicznego wymiaru nauki, dz. cyt., s. 90-91.

$15 \mathrm{~W}$ dyskusji nad obecnością wartości w wewnętrznej strukturze nauki w piśmiennictwie spotyka się m.in. rozróżnienie na: a) wartości poznawcze - związane z poszerzaniem wiedzy i b) pozapoznawcze - niezwiązane bezpośrednio ze zdobywaniem wiedzy o przedmiocie badania. Por. A. Lekka-Kowalik, Odkrywanie aksjologicznego wymiaru nauki, dz. cyt., s. 316. 
Ograniczę się do przytoczenia argumentu, który może posłużyć jako przykład obecności wartości moralnych w naukach biomedycznych.

Michael Scriven w jednej ze swych prac podaje przykład hipotetycznej sytuacji badawczej, której celem jest wskazanie skutecznej metody zachowania dyscypliny w szkole. Behawiorysta proponuje, aby uczniów podłączyć do konsolety sterowanej przez nauczyciela, po czym naruszających dyscyplinę poddawać działaniu elektrowstrząsów. Autor zastanawia się, czy zaproponowane rozwiązanie jest właściwe czy też nie. W odpowiedzi podaje, że takie podejście jest nieodpowiednie, gdyż pomija względy moralne ${ }^{16}$. Na podstawie tego przykładu można spróbować wskazać, gdzie znajdują się wartości moralne. Analizę tego przypadku przeprowadza Agnieszka Lekka-Kowalik, która uznaje, że w tej sytuacji wybór środków (metody badawczej) nierozerwalnie wiąże się z ustaleniem, kim lub czym jest uczeń będący przedmiotem badania. Wybierając jakiś sposób działania (metodologia), zakłada się (świadomie lub nieświadomie) jaką́ koncepcję rozumienia ucznia/człowieka (np. posiadającego godność lub jej pozbawionego). Niezależnie od tego, jaką koncepcję (czysto behawioralną czy personalistyczną) wybierze naukowiec, dokonuje on sądu o charakterze opisowo-wartościującym na temat przedmiotu badania ( $w$ tym wypadku ucznia). W związku z tym, w celu przeprowadzenia badania naukowiec świadomie bądź intuicyjnie formułuje sądy wartościujące pozapoznawczo (moralne), które stanowią nierozerwalny element nauki ${ }^{17}$.

Przytoczony przykład można przełożyć na grunt nauk biomedycznych. Wyobraźmy sobie zespół naukowców, który opracował nowy lek na rdzeniowy zanik mięśni, poważną chorobę neurodegeneracyjną. Po uzyskaniu obiecujących wyników testów na zwierzętach badacze przechodzą do etapu testowania leku na zdrowych ochotnikach w ramach badania klinicznego ${ }^{18}$. Głównym celem projektu jest określenie

16 Zob. M. Scriven, The exact role of value judgements in science, w: Ethical Issues in Scientific Research, eds. E. Erwin, S. Gendin, L. Kleiman, New York 1994, s. 29-50.

17 Zob. A. Lekka-Kowalik, Odkrywanie aksjologicznego wymiaru nauki, dz. cyt., s. 113-117.

18 Badanie kliniczne jest szczególnym rodzajem badania naukowego przeprowadzanego na ludziach w celu określenia wpływu danej substancji leczniczej lub urządzenia medycznego na organizm człowieka; por. T. Brodniewicz, Badania kliniczne, Warszawa 2015. 
zakresu bezpiecznych dawek leku, które będzie można później przebadać na większej grupie pacjentów cierpiących na tę chorobę. W cyklu zaplanowanych doświadczeń badany będzie wpływ działania różnych dawek leku na zdrowie uczestników. Chodzi zatem o poznanie, przy jakich dawkach lek będzie powodował poważne problemy zdrowotne lub okaże się letalny. Tak zaplanowane badanie niewątpliwie będzie miało wartość poznawczą, jednak z punktu widzenia etyki projekt jawi się jako jednoznacznie niedopuszczalny. Będzie zasługiwał na dyskwalifikację nie ze względu na jego poznawczą nieskuteczność (nadal przyniósłby dane naukowe na temat wpływu leku na organizm), lecz dlatego, iż przyjęta metoda jest skrajnie niebezpieczna dla pacjentów.

Przedstawiony przykład jest mocno przejaskrawiony, niemniej dzięki temu wyraźniej obrazuje zastrzeżenia natury etycznej związane $\mathrm{z}$ doborem metodologii badania. Odrzucenie przyjętej metody badawczej dokonywane jest tutaj na podstawie wcześniejszej oceny wyboru przedmiotu badania, jakim jest dorosły człowiek. W ocenie tej pojawia się dodatkowa przesłanka na temat statusu moralnego uczestnika badania. Status ten nakazuje ochronę życia i zdrowia człowieka, co w efekcie jednoznacznie wyklucza dopuszczalność zastosowania wspomnianej metody badań na ludziach. Dodatkowo moralny status uczestników nakłada na przeprowadzających projekt wymóg doboru takich metod i warunków eksperymentu, w których zachowane będą maksymalne środki ostrożności, zapewniające bezpieczeństwo uczestnikom. Negatywna kwalifikacja moralna wspomnianej metody wynika $\mathrm{z}$ uwzględnienia w niej wartości moralnych.

Podsumowując opisany wyżej przykład, w procesie realizacji badania naukowiec nieuchronnie staje przed wyborem metody badawczej - wydaje ściśle określony moralny sąd wartościujący w odniesieniu do stosowanych procedur badawczych. Dlatego też zakładając, że badanie naukowe to seria wielu konkretnych decyzji i wyborów, trudno uznać, iż sądy na temat wartości moralnych nie wchodzą w zakres działalności naukowej. Zadaniem naukowca, oprócz dbałości o skuteczność w osiągnięciu celu poznawczego, jest jednocześnie uwzględnienie aspektu moralnego w przebiegu określonego badania naukowego. „To naukowiec 
jako naukowiec planuje badania i nikt nie może go w tej funkcji zastąpić. Wydane przez niego sądy wartościujące i pochodne od nich sądy normatywne kształtują badanie naukowe rozumiane jako zbiór czynności, a zarazem wchodzą w treść nauki, a dokładnie w jej część stanowiącą zbiór twierdzeń o sposobach zdobywania wiedzy o świecie"19.

Z nakreślonych pokrótce analiz nasuwa się następujący wniosek. Nauka rozumiana jako praktyka badawcza wymaga od badacza również podejmowania określonych decyzji moralnych. Odnosząc te wnioski do zadanego we wstępie pytania o neutralność moralną biotechnologii, należy stwierdzić, że kwalifikacji etycznej podlegają nie tylko jej zastosowania, lecz także elementy składające się na proces prowadzonych w jej ramach badań naukowych.

\section{Etyczny wymiar biotechnologii}

Wartości moralne niejako wpisane są w wewnętrzny kontekst aktywności, jaką jest praca naukowa. Wynika to $\mathrm{z}$ faktu, iż na każdym etapie realizacji dokonuje się wielu działań, które nie są neutralne moralne. Szczególnie wyraźnie uzewnętrznia się aspekt moralny przy doborze odpowiedniej metody do osiągnięcia założonych celów badawczych. Biotechnologia, rozumiana jako pewien szczegółowy rodzaj działalności naukowej, nie stanowi zatem wyjątku, jeśli chodzi o przedmiot kwalifikacji moralnej czynów człowieka. Różnica polega jedynie na tym, że w biotechnologii nieustannie pojawiają się nowe i często wyjątkowo trudne do oceny kwestie etyczne, zarówno w trakcie prowadzenia badań, jak i w procesie wdrażania nowych technologii do codziennej praktyki. Jednakże, pomimo nieustannego rozwoju nauk biomedycznych, pewne podstawowe zasady moralne pozostają niezmienne. Choć zakres działań człowieka $w$ ramach biotechnologii nieustannie się powiększa, to nadal jest on częścią rzeczywistości, w której obowiązują te same ogólne normy moralne, jakimi kierujemy się w codziennym życiu. 
Większe możliwości techniczne nie dezaktualizują ogólnych norm postępowania ${ }^{20}$.

Normy te z założenia mają na celu ochronę dobra człowieka. Jeśli przyjąć, że celem nauki jest zawsze dobro człowieka, to powinno się ją uprawiać z uwzględnieniem zasad moralnych stojących na straży wartości człowieka. Aktualizacji oraz doprecyzowania wymagać będą pewne szczegółowe rozstrzygnięcia moralne odnoszące się m.in. do powstających w ramach nauk biomedycznych nowych możliwości technicznych, metod badawczych, narzędzi diagnostycznych itp. Szczegółowe wskazówki moralne powinny być jednak zgodne z ogólnymi pryncypiami, zasadami etycznymi, jakimi kierujemy się w życiu codziennym ${ }^{21}$.

Pozytywna ocena etyczna działań naukowych zależeć będzie jednak od tego, czy biotechnolog w swojej pracy dokonał wszelkich starań, by wartości moralne nie zostały pogwałcone. Ostatecznie bowiem wartości moralne w nauce zostają poszanowane wtedy, gdy chronione będzie dobro człowieka na wszystkich etapach działań naukowych. Ważne jest zatem określenie, co jest dobre dla człowieka. Aby jednak zdecydować, jakie działania są dobre, niezbędne jest wcześniejsze zrozumienie, kim jest człowiek i jaka jest jego prawdziwa natura. Stąd we wszelkich rozważaniach nad etosem nauki kluczowe jest uwzględnienie prawd odkrywanych w obrębie antropologii filozoficznej.

Ukazuje się tutaj wyraźnie antropologiczny charakter nauki. Jedynie bowiem odpowiedź na pytanie, kim jest człowiek i jak powinien żyć, pozwala podjąć próbę wytyczenia kierunku rozwoju nauki. W projektach biotechnologicznych, w których przedmiotem badań jest człowiek, natura ludzka nabiera charakteru normatywnego. Pominięcie natury ludzkiej w realizacji badań naukowych grozi sprzeniewierzeniem się człowiekowi. Uprawomocnieniem wszelkich działań dokonywanych w ramach biotechnologii jest dbałość o dobro człowieka traktowanego zgodnie $\mathrm{z}$ jego osobową naturą.

20 Por. T. Ślipko, Bioetyka. Najważniejsze problemy, Kraków 2012, s. 128-129.

${ }^{21}$ Por. G. Hołub, Czy rozwój nauk biomedycznych wymaga nowej etyki?, w: Historia i przyszłość bioetyki, red. J. Brusiło, Kraków 2009, s. 153-166. 
Uwzględnienie wymiaru antropologicznego nauki może dokonywać się w ramach etyki badań naukowych. Problem polega na tym, że w filozofii znajdujemy wiele konkurencyjnych koncepcji rozumienia człowieka. Nie bez znaczenia będzie zatem, z jakiego nurtu filozoficznego etyka badań naukowych będzie czerpać uzasadnienia proponowanych przez nią rozwiązań. Sądzę, iż w poszukiwaniach uzasadnienia norm moralnych cenne jest odwołanie się do rozstrzygnięć, które znajdujemy w etyce personalistyczno-tomistycznej. Zgodnie z założeniami tego kierunku myślowego, człowiek ujmowany jest jako nierozerwalna jedność ciała i ducha. Jedność ta, wyrażająca się chociażby w doświadczeniu własnej podmiotowości, oparta jest na osobowym charakterze istnienia człowieka. To właśnie w pojęciu osoby wyraża się pełnia jedności bytowej natury ludzkiej. W personalizmie za nadrzędną wartość związaną z naturą ludzką uznaje się godność osobową ${ }^{22}$.

Większość prób mających na celu zdefiniowanie godności osoby koncentruje się na fakcie, że godność jako wartość związana jest ze specyficznym sposobem istnienia człowieka. Personalistyczne rozumienie osoby ludzkiej opiera się na koncepcji osoby ujmowanej jako istnienie substancjalne. Dlatego też uznanie bytu za osobę ludzką prowadzi do przyznania mu jednocześnie wrodzonej i niezbywalnej godności osobowej, a co za tym idzie wiąże się z pojawieniem się pewnych konkretnych obowiązków moralnych. Andrzej Szostek dokonuje próby uchwycenia zjawiska godności w następujący sposób: „natura człowieka odróżnia go od innych bytów nie tylko w sensie czysto opisowym, ale i aksjologicznym; z racji tego, kim jest, człowiek jest cenniejszy niż inne byty na ziemi. Cenność tę $[\ldots]$ określa się mianem godności osobowej”23. Ze względu na wartość, jaką jest godność osoby, każda osoba ludzka winna być zawsze traktowana w sposób, który wiąże się z jej adekwatnym poszanowaniem.

22 Por. P. Jaroszyński, Personalizm filozoficzny - integralna wizja człowieka, w: Zadania wspótczesnej metafizyki, t. 9: Dusza. Umyst. Ciało, Lublin 2007, s. 473-485.

${ }^{23}$ A. Szostek, Wokót godności, prawdy i miłości. Rozważania etyczne, Lublin 1998, s. 46. 
Czerpiąc zatem z osiągnięć personalizmu tomistycznego, dochodzimy do wniosku, że w centrum wszystkich działań człowieka, w tym pracy naukowej, winno być dobro osoby ludzkiej. Poprzestanie na odwołaniu się do dobra człowieka jako celu nauki okazuje się jednak zbyt ogólne i niewystarczające. Pojęcie dobra człowieka domaga się pełniejszego doprecyzowania, szczególnie jeśli chodzi o biotechnologię. W próbie dookreślenia, o jakie dobro człowieka chodzi, warto posłużyć się propozycją prezentowaną przez amerykańskiego bioetyka Edmunda D. Pellegrina. Podaje on cztery podstawowe rodzaje dobra osoby: a) dobro kliniczne i medyczne; b) dobro subiektywne - przeżywane przez człowieka; c) dobro ontyczne - dobro człowieka jako osoby; d) dobro duchowe człowie$\mathrm{ka}^{24}$. W celu ochrony dobra człowieka, będącego przedmiotem badań nauk biomedycznych, istotne będzie uwzględnienie nie tylko dobra klinicznego związanego z cielesnością człowieka, lecz w równej mierze także pozostałych, wyżej wymienionych rodzajów dóbr. W nauce należy zatem wziąć pod uwagę wszystkie aspekty rozumienia dobra osoby ludzkiej, a nie tylko dobra utylitarne czy pragmatyczne. Ważne jest więc, aby naukowiec zdał sobie sprawę, że badany przedmiot, jakim jest człowiek, posiada wartość przekraczającą znaczenie jego funkcji biologicznych. Wartością tą jest godność osoby ludzkiej.

Kiedy bierzemy pod uwagę taką koncepcję rozumienia natury ludzkiej, ukazują się nam niejako ogólne zasady moralne, które powinny obowiązywać biotechnologa. Głównym założeniem w praktyce biotechnologicznej winno być dobieranie takich warunków przeprowadzania wszelkich eksperymentów, w których człowiek nie jest traktowany jak przedmiot, lecz byt materialno-duchowy. W biotechnologii, a więc nauce, w której możliwe jest ingerowanie w biologiczną strukturę człowieka już od najwcześniejszych etapów jego rozwoju, szczególnie istotne będzie zatem uwzględnienie statusu ontycznego bytu ludzkiego.

Dostrzegając zatem fakt, iż w ramach swojej praktyki biotechnolog nieuchronnie staje w obliczu pewnych ściśle określonych wartości, a tym

24 Za: G. Hołub, Osoba w labiryncie decyzji moralnych. Bioetyka w perspektywie personalistycznej, Kraków 2014, s. 71. 
samym przed koniecznością podejmowania ważnych decyzji o charakterze moralnym, w pierwszej kolejności powinien on dokonać oceny, $\mathrm{z}$ jakim bytem ma do czynienia $\mathrm{w}$ planowanych przez siebie badaniach. Wielokrotnie bowiem przedmiotem jego eksperymentów są jednostki biologiczne (jak np. zarodek ludzki), które zgodnie $\mathrm{z}$ antropologią tomistyczną posiadają status osoby ludzkiej. Dostrzeżenie wartości oraz dóbr związanych z osobową naturą ludzką obliguje tym samym biotechnologa do ochrony życia ludzkiego, troski o jego jakość, unikania działań, w których jedno życie poświęcane jest dla życia innych czy też ratowane kosztem uśmiercania innego. Zasady te są jedynie ogólnym fundamentem etycznym wynikającym wprost $\mathrm{z}$ wiedzy na temat natury ludzkiej. Stanowią konieczny punkt wyjścia w konstruowaniu bardziej szczegółowych norm, jakie powinny obowiązywać w biotechnologii. Moim celem nie było przedstawienie pełnej wyczerpującej listy takich norm, lecz jedynie zwrócenie uwagi na to, iż tworzenie takich zasad $\mathrm{w}$ biotechnologii powinno uwzględniać integralne, cielesno-duchowe rozumienie bytowości człowieka. Jest to przestrzeń do dalszych badań w tym zakresie. Dostrzegam tutaj konieczność tworzenia pewnych szczegółowych kodeksów postępowania opartych na możliwie najwłaściwszym i najpełniejszym ujęciu natury ludzkiej. Tylko w takim ujęciu można sformułować zasad pracy naukowej, w której dobro człowieka zostanie poszanowane.

\section{Bibliografia}

Brodniewicz T., Badania kliniczne, Warszawa 2015.

Chmiel A., Biotechnologia. Podstawy mikrobiologiczne i biochemiczne, Warszawa 1998.

Dorocki S., Jastrzębski J. P., Regionalne zróżnicowanie rozwoju biotechnologii w Europie, „Prace Komisji Geografii Przemysłu Polskiego Towarzystwa Geograficznego” 20 (2012), s. 67-94.

Dubin A., Stan i kierunki rozwoju biogospodarki, w: Raport opracowany przez Interdyscyplinarny Zespół do spraw Rozwoju Biogospodarki MNiSW, Warszawa 2007, s. 17-18. Hajduk Z., Nauka a wartości. Aksjologia nauki, Lublin 2008. 
Hołub G., Czy rozwój nauk biomedycznych wymaga nowej etyki?, w: Historia i przyszłość bioetyki, red. J. Brusiło, Kraków 2009, s. 153-166.

Hołub G., Osoba w labiryncie decyzji moralnych. Bioetyka w perspektywie personalistycznej, Kraków 2014.

Jaroszyński P., Personalizm filozoficzny - integralna wizja człowieka, w: Dusza. Umyst. Ciało, red. A. Maryniarczyk, K. Stępień, Lublin 2007, s. 473-485 (Zadania Współczesnej Metafizyki, 9).

Kafarski P., Tęczowy kod biotechnologii, „Chemik” 66 (2012) nr 8, s. 811-816.

Lekka-Kowalik A., Odkrywanie aksjologicznego wymiaru nauki, Lublin 2008.

Lekka-Kowalik A., Związek nauki i techniki jako źródło problematyki dla etyki badań naukowych, w: Kultura wobec techniki, red. P. Gondek, Lublin 2004, s. 147-165.

Paszewski A., Sukcesy naukowe a problemy etyczne, „Postępy Mikrobiologii” 39 (2000), s. 9-15.

Rodzeń J., W stronę aksjologii nauki, „Zagadnienia Filozoficzne w Nauce” 24 (1999), s. 3-6. Scriven M., The exact role of value judgements in science, w: Ethical Issues in Scientific Research, eds. E. Erwin, S. Gendin, L. Kleiman, New York 1994, s. 29-50.

Stępień A., Wstęp do filozofii, Lublin 2007.

Szostek A., Wokół godności, prawdy i miłości. Rozważania etyczne, Lublin 1998.

Ślipko T., Bioetyka. Najważniejsze problemy, Kraków 2012.

Weber M., Sens wolnej od wartościowań socjologii i ekonomii, w: Problemy socjologii wie$d z y$, red. E. Nowakowska-Sołtan, Warszawa 1985, s. 101-148.

\section{Abstrakt \\ W poszukiwaniu aksjologicznych podstaw dla etyki działań biotechnologicznych}

Biotechnologia należy do jednej z najszybciej rozwijających się dziedzin nauki. We współczesnej debacie bioetycznej nierzadko spotkać można opinię wskazującą na to, że biotechnologię jako naukę należy uznać za etycznie neutralną, a jedynie jej zastosowania powinny podlegać kwalifikacji moralnej. Zaprezentowana w artykule charakterystyka biotechnologii skłania autora do zaproponowania tezy przeciwnej. W pracy badawczej biotechnolog napotyka zagadnienia domagające się podejmowania decyzji o charakterze moralnym. Stąd w artykule przedstawiono pogląd, iż praktyka naukowa należąca 
do biotechnologii „nasycona” jest wartościami moralnymi. Uznanie aksjologicznego i etycznego wymiaru biotechnologii prowadzi jednocześnie do wniosku, że w codziennej praktyce badawczej naukowiec winien świadomie uwzględnić moralne aspekty swoich działań oraz wziąć pod uwagę dobro osoby ludzkiej. W artykule zaproponowano również ogólny model etosu biotechnologa oparty na etyce personalistyczno-tomistycznej.

\section{Słowa kluczowe}

biotechnologia, nauka, etyka, aksjologia, wartości moralne, personalizm, osoba, godność

\section{Abstract \\ In search of axiological basis for the ethics of biotechnology}

Biotechnology is one of the most rapidly progressing field of modern science. In contemporary bioethical debate one can frequently find views, stating that biotechnology as a field of science is ethically neutral and only its applications should be evaluated ethically. Based on the description of biotechnology presented herein, the author of the article supports the opposite thesis. In scientific work biotechnologist frequently meets issues that require moral decisions to be made. Therefore, the article presents the view, that scientific practice in the field of biotechnology is filled with moral values (value-ladenness of science). Accepting axiological and ethical context of modern biotechnology leads us to the conclusion that in daily scientific practice scientists should consciously take into account moral aspects of their activity and also attract their attention to protect the good of human person. In addition, the article presents the basic model of biotechnologist's ethos based on Thomistic Personalism.

\section{Keywords}

biotechnology, science, ethics, axiology, moral values, personalism, person, dignity 